\title{
Chryseobacterium daeguense sp. nov., isolated from wastewater of a textile dye works
}

Correspondence

Jung-Hoon Yoon

jhyoon@kribb.re.kr

\author{
Jung-Hoon Yoon, So-Jung Kang and Tae-Kwang Oh \\ Korea Research Institute of Bioscience and Biotechnology (KRIBB), PO Box 115, Yusong, \\ Taejon, Korea
}

\begin{abstract}
A Gram-negative, rod-shaped bacterial strain, $\mathrm{K} 105^{\top}$, was isolated from wastewater of a textile dye works in Korea and subjected to a polyphasic taxonomic study. Strain $\mathrm{K} 105^{\top}$ grew optimally at $\mathrm{pH} 6.5-7.5$ and $30-37^{\circ} \mathrm{C}$. It contained MK- 6 as the predominant menaquinone and iso- $\mathrm{C}_{15: 0}$, iso- $\mathrm{C}_{17: 1} \omega 9 \mathrm{c}$, iso- $\mathrm{C}_{17: 0} 3-\mathrm{OH}$ and summed feature $3\left(\mathrm{C}_{16: 1} \omega 7 \mathrm{c}\right.$ and/or iso- $\left.\mathrm{C}_{15: 0} 2-\mathrm{OH}\right)$ as the major fatty acids. The DNA G $+C$ content was $36.8 \mathrm{~mol} \%$. Phylogenetic analysis based on 16S rRNA gene sequences showed that strain $\mathrm{K}_{105^{\top}}$ belonged to the genus Chryseobacterium. Strain $\mathrm{K}_{105}{ }^{\top}$ exhibited $16 \mathrm{~S}$ rRNA gene sequence similarity values of less than $96.9 \%$ to the type strains of recognized Chryseobacterium species. Strain $\mathrm{K} 105^{\top}$ differed from phylogenetically related Chryseobacterium species in several phenotypic properties. On the basis of phenotypic and phylogenetic data, strain $\mathrm{K} 105^{\top}\left(=\mathrm{KCTC} 12841^{\top}=\mathrm{JCM} 14362^{\top}\right)$ is placed in the genus Chryseobacterium as the type strain of a novel species, for which the name Chryseobacterium daeguense sp. nov. is proposed.
\end{abstract}

The genus Chryseobacterium was proposed by Vandamme et al. (1994) and, at the time of writing, the genus comprised 19 recognized species, including the recently described species Chryseobacterium soldanellicola and Chryseobacterium taeanense (Park et al., 2006), Chryseobacterium piscium (de Beer et al., 2006), Chryseobacterium wanjuense (Weon et al., 2006), Chryseobacterium hispanicum (Gallego et al., 2006), Chryseobacterium taiwanense (Tai et al., 2006) and Chryseobacterium caeni (Quan et al., 2007). Here we report on the taxonomic characterization of a Chryseobacteriumlike bacterial strain, $\mathrm{K} 105^{\mathrm{T}}$, which was isolated from wastewater of a textile dye works in Daegu, Korea.

Strain $\mathrm{K} 105^{\mathrm{T}}$ was isolated by using the standard dilution plating technique on trypticase soy agar (TSA; Difco) at $30{ }^{\circ} \mathrm{C}$. The morphological, physiological and biochemical characteristics of strain $\mathrm{K}_{105^{\mathrm{T}}}$ were investigated using routine cultivation on TSA at $30^{\circ} \mathrm{C}$. The morphology and flagellation of cells from exponentially growing cultures were examined using light microscopy (Nikon E600) and transmission electron microscopy (Philips CM-20). For the latter purpose, cells were negatively stained with $1 \%(\mathrm{w} / \mathrm{v})$ phosphotungstic acid and the grids were examined after being air-dried. Gliding motility was determined as described by Bowman (2000) using quarter-strength trypticase soy broth (TSB; Difco) solidified with $1 \%(\mathrm{w} / \mathrm{v})$ agarose and

\footnotetext{
The GenBank/EMBL/DDBJ accession number for the 16S rRNA gene sequence of strain $\mathrm{K} 105^{\top}$ is EF076759.

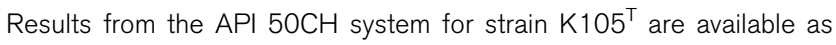
supplementary material with the online version of this paper.
}

R2A agar (Difco). The Gram reaction was determined using the bioMérieux Gram stain kit according to the manufacturer's instructions. Growth at various temperatures (4$45^{\circ} \mathrm{C}$ ) was measured on TSA. Growth in the absence of $\mathrm{NaCl}$ and at various $\mathrm{NaCl}$ concentrations $(0.5 \%$ and $1.0-5.0 \%$, $\mathrm{w} / \mathrm{v}$, at intervals of $1.0 \%$ ) was investigated using TSB prepared according to the formula of the Difco medium except that $\mathrm{NaCl}$ was excluded. The $\mathrm{pH}$ range for growth was determined in nutrient broth (NB; Difco) adjusted, prior to sterilization, to various $\mathrm{pH}$ values $(\mathrm{pH} 4.5-10.5$ at intervals of $0.5 \mathrm{pH}$ units) by the addition of $\mathrm{HCl}$ or $\mathrm{Na}_{2} \mathrm{CO}_{3}$. Growth under anaerobic conditions was determined after incubation in an anaerobic chamber on plain TSA and on TSA supplemented with potassium nitrate $(0.1 \%, \mathrm{w} / \mathrm{v})$, both of which had been prepared anaerobically under a nitrogen atmosphere. Catalase and oxidase activities and hydrolysis of casein, gelatin, xanthine, hypoxanthine, starch, Tweens 20, 40, 60 and 80, tyrosine and urea were determined as described by Cowan \& Steel (1965). DNase activity was examined by using DNase test agar with methyl green (Difco). Hydrolysis of aesculin and nitrate reduction were studied as described previously (Lanyi, 1987). The presence of flexirubin-type pigments was investigated as described by Reichenbach (1992). Susceptibility to antibiotics was tested on TSA plates using antibiotic discs containing the following amounts: polymyxin $\mathrm{B}, 100 \mathrm{U}$; streptomycin, $50 \mu \mathrm{g}$; penicillin G, $20 \mathrm{U}$; chloramphenicol, $100 \mu \mathrm{g}$; ampicillin, $10 \mu \mathrm{g}$; cephalothin, $30 \mu \mathrm{g}$; gentamicin, $30 \mu \mathrm{g}$; novobiocin, $5 \mu \mathrm{g}$; tetracycline, $30 \mu \mathrm{g}$; kanamycin, $30 \mu \mathrm{g}$; lincomycin, $15 \mu \mathrm{g}$; oleandomycin, $15 \mu \mathrm{g}$; neomycin, $30 \mu \mathrm{g}$; and carbenicillin, $100 \mu \mathrm{g}$. Assimilation of and acid production from 
various substrates, enzyme activities and other physiological and biochemical properties were tested by using the API 20E, API 20NE, API 50CH and API ZYM systems (bioMérieux). The API 50CH system was inoculated with cell suspensions in API 50 CHB medium and AUX medium for assessing acid production from and assimilation of various substrates, respectively, according to the manufacturer's instructions.

Cell biomass for DNA extraction and for isoprenoid quinone analysis was obtained from cultivation in TSB at $30{ }^{\circ} \mathrm{C}$. Chromosomal DNA was isolated and purified according to the method described by Yoon et al. (1996), with the exception that RNase T1 was used in combination with RNase A to minimize contamination with RNA. The 16S rRNA gene was amplified by PCR using two universal primers as described previously (Yoon et al., 1998). Sequencing of the amplified 16S rRNA gene and phylogenetic analysis were performed as described by Yoon et al. (2003). Isoprenoid quinones were extracted according to the method of Komagata \& Suzuki (1987) and analysed using reversed-phase HPLC and a YMC ODS-A $(250 \times 4.6 \mathrm{~mm})$ column. For fatty acid analysis, cell mass of strain $\mathrm{K} 105^{\mathrm{T}}$ was harvested from TSA plates after incubation for 2 days at $30^{\circ} \mathrm{C}$. The fatty acids were extracted and fatty acid methyl esters were prepared according to the standard protocol of the MIDI/Hewlett Packard Microbial Identification System (Sasser, 1990). The DNA G + C content was determined by the method of Tamaoka \& Komagata (1984) with the modification that DNA was hydrolysed and the resultant nucleotides were analysed by reversed-phase HPLC.

Morphological, cultural, physiological and biochemical characteristics of strain $\mathrm{K}_{105^{\mathrm{T}}}$ are given in the species description (see below), in Table 1 and in Supplementary Table S1 in IJSEM Online. The almost complete 16S rRNA gene sequence of strain $\mathrm{K} 105^{\mathrm{T}}$ determined in this study comprised 1472 nucleotides, representing approximately
$96 \%$ of the Escherichia coli 16S rRNA gene sequence. Phylogenetic analysis based on $16 \mathrm{~S}$ rRNA gene sequences showed that strain $\mathrm{K} 105^{\mathrm{T}}$ fell among Chryseobacterium species (Fig. 1). Strain $\mathrm{K}_{105^{\mathrm{T}}}$ exhibited $16 \mathrm{~S}$ rRNA gene sequence similarity values of $94.4-96.9 \%$ with the type strains of recognized Chryseobacterium species and of less than $93.3 \%$ with all other species included in the phylogenetic analysis (Fig. 1).

The predominant isoprenoid quinone detected in strain $\mathrm{K} 105^{\mathrm{T}}$ was menaquinone- 6 (MK-6), at a peak area ratio of approximately $90 \%$; this is consistent with other Chryseobacterium species (Vandamme et al., 1994; Kämpfer et al., 2003; Kim et al., 2005; Tai et al., 2006; Weon et al., 2006). The fatty acid profile of strain $\mathrm{K}_{105^{\mathrm{T}}}$ comprised $(>0.5 \%$ of total fatty acids) the branched fatty acids iso- $\mathrm{C}_{15: 0}(37.8 \%)$, iso- $\mathrm{C}_{17: 1} \omega 9 c(21.1 \%)$, iso- $\mathrm{C}_{13: 0}(0.7 \%)$, anteiso- $\mathrm{C}_{15: 0}$ $(0.6 \%)$ and iso- $\mathrm{C}_{17: 0}(0.6 \%)$, the hydroxy fatty acids iso$\mathrm{C}_{17: 0} 3-\mathrm{OH}(18.9 \%)$, iso- $\mathrm{C}_{15: 0} 3-\mathrm{OH}(4.0 \%)$ and $\mathrm{C}_{16: 0} 3-$ $\mathrm{OH}(1.2 \%)$, summed feature 3 (comprising $\mathrm{C}_{16: 1} \omega 7 \mathrm{c}$ and/ or iso- $\left.\mathrm{C}_{15: 0} 2-\mathrm{OH} ; 10.3 \%\right)$, the straight-chain fatty acid $\mathrm{C}_{16: 0}(0.9 \%)$, the unknown fatty acids ECL $16.582(1.2 \%)$ and ECL $13.565(1.0 \%)$ and the unsaturated fatty acid $\mathrm{C}_{18: 1} \omega 5 c(0.8 \%)$. This fatty acid profile was similar to those of other Chryseobacterium species, although there were differences in the proportions of some fatty acids, probably because of differences in cultivation conditions and extraction procedures (Vandamme et al., 1994; Kämpfer et al., 2003; Kim et al., 2005; Park et al., 2006; de Beer et al., 2006; Tai et al., 2006; Weon et al., 2006). The DNA G +C content of strain $\mathrm{K} 105^{\mathrm{T}}$ was $36.8 \mathrm{~mol} \%$. Chemotaxonomic data confirm the phylogenetic affiliation of strain $\mathrm{K}_{105^{\mathrm{T}}}$ as a member of the genus Chryseobacterium. Strain $\mathrm{K}_{105^{\mathrm{T}}}$ is distinguishable from phylogenetically related Chryseobacterium species by differences in several phenotypic properties, as shown in Table 1. The phylogenetic distinctiveness,

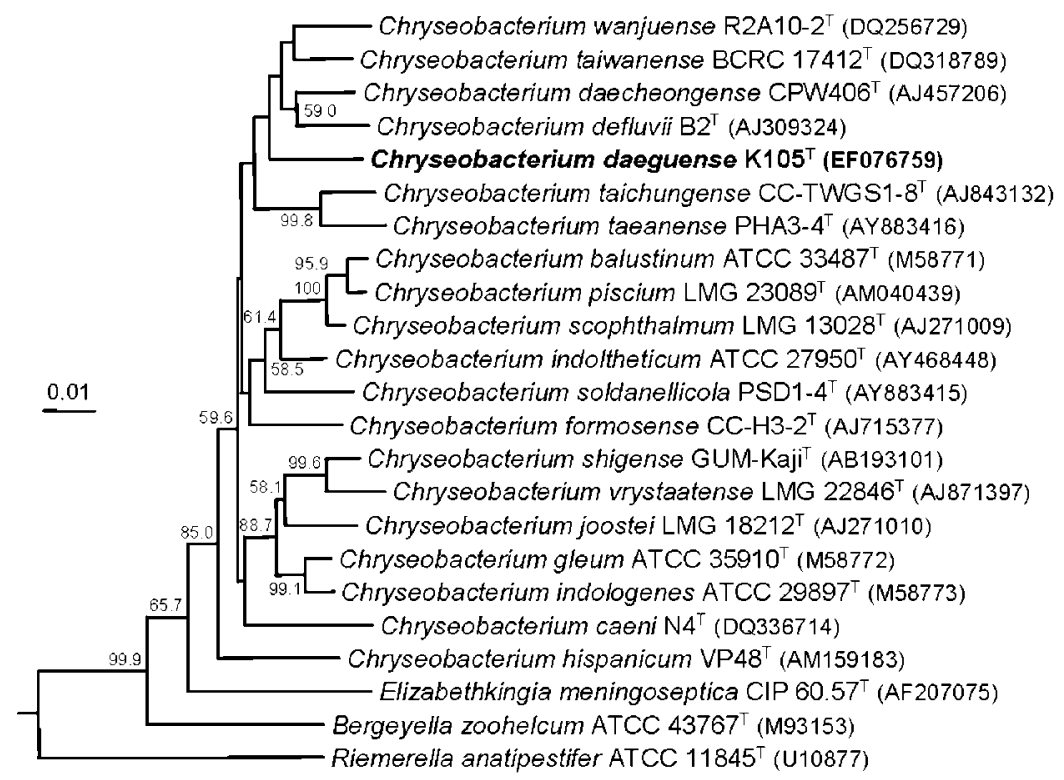

Fig. 1. Neighbour-joining phylogenetic tree based on 16S rRNA gene sequences showing the positions of Chryseobacterium daeguense sp. nov. $\mathrm{K} 105^{\top}$, other Chryseobacterium species and some other related taxa. Bootstrap values (expressed as percentages of 1000 replications) $>50 \%$ are shown at branching points. Cytophaga hutchinsonii ATCC $33406^{\top}$ (GenBank accession no. M58768) was used as an outgroup (not shown). Bar, 0.01 substitutions per nucleotide position. 
Table 1. Differential phenotypic characteristics of strain $\mathrm{K} 105^{\top}$ and phylogenetically related Chryseobacterium species

Taxa: 1, strain $\mathrm{K}_{105^{\mathrm{T}}}$ (C. daeguense sp. nov.); 2, C. daecheongense (data from Kim et al., 2005); 3, C. defluvii (Kämpfer et al., 2003; Kim et al., 2005); 4, C. taeanense (Park et al., 2006); 5, C. taichungense (Shen et al., 2005; Park et al., 2006; Weon et al., 2006); 6, C. taiwanense (Tai et al., 2006); 7, C. wanjuense (Weon et al., 2006). +, Positive ; -, negative ; W, weakly positive ; ND, no data available. All species are Gram-negative, non-spore-forming rods. All species are positive for oxidase (not determined for C. wanjuense), growth at $37^{\circ} \mathrm{C}$, hydrolysis of aesculin and gelatin, production of flexirubin-type pigments (not determined for C. taeanense), alkaline phosphatase, esterase lipase (C8), leucine arylamidase, valine arylamidase, acid phosphatase and naphthol-AS-BI-phosphohydrolase. All species are negative for motility (not determined for C. taeanense or C. wanjuense), urea hydrolysis (not determined for C. taiwanense), $\mathrm{H}_{2} \mathrm{~S}$ production (not determined for $C$. wanjuense), acid production from lactose, mannitol, sucrose (not determined for C. taeanense) and salicin (not determined for C. taeanense or C. taiwanense) and $\alpha$-galactosidase, $\alpha$-mannosidase and $\alpha$-fucosidase activities.

\begin{tabular}{|c|c|c|c|c|c|c|c|}
\hline Characteristic & 1 & 2 & 3 & 4 & 5 & 6 & 7 \\
\hline \multicolumn{8}{|l|}{ Growth at: } \\
\hline $5^{\circ} \mathrm{C}$ & - & - & - & + & - & + & + \\
\hline Growth on MacConkey agar & - & - & - & - & - & $\mathrm{ND}$ & $\mathrm{W}$ \\
\hline Indole production & - & - & + & - & $\mathrm{W}$ & + & - \\
\hline \multicolumn{8}{|l|}{ Hydrolysis of: } \\
\hline Casein & + & + & + & $\mathrm{ND}$ & ND & + & + \\
\hline DNA & + & $\mathrm{ND}$ & $\mathrm{ND}$ & - & $\mathrm{ND}$ & $\mathrm{ND}$ & $\mathrm{w}$ \\
\hline Starch & + & + & + & $\mathrm{ND}$ & $\mathrm{ND}$ & + & + \\
\hline \multicolumn{8}{|l|}{ Acid produced from: } \\
\hline Glycerol & - & + & $\mathrm{ND}$ & - & $\mathrm{ND}$ & - & - \\
\hline Maltose & + & - & + & - & + & - & - \\
\hline Raffinose & - & + & - & $\mathrm{ND}$ & - & + & - \\
\hline D-Trehalose & + & + & + & - & + & - & + \\
\hline D-Xylose & $\mathrm{w}$ & + & - & - & + & $\mathrm{ND}$ & - \\
\hline \multicolumn{8}{|l|}{ Utilization of: } \\
\hline L-Arabinose & + & - & - & + & - & $\mathrm{ND}$ & - \\
\hline Glucose & + & + & + & + & - & $\mathrm{ND}$ & + \\
\hline Fructose & + & - & - & + & - & ND & $\mathrm{ND}$ \\
\hline Mannose & + & + & + & + & - & ND & + \\
\hline Rhamnose & + & - & - & + & - & $\mathrm{ND}$ & - \\
\hline Cystine arylamidase & - & - & - & - & + & - & $\mathrm{w}$ \\
\hline Trypsin & - & - & - & - & + & - & - \\
\hline$\alpha$-Chymotrypsin & - & + & + & - & + & - & $\mathrm{W}$ \\
\hline$\beta$-Galactosidase & - & - & - & - & $\mathrm{W}$ & - & - \\
\hline$\beta$-Glucuronidase & - & - & - & - & + & - & - \\
\hline$\alpha$-Glucosidase & + & - & + & + & + & + & $\mathrm{W}$ \\
\hline$\beta$-Glucosidase & - & - & - & + & + & - & - \\
\hline$N$-Acetyl- $\beta$-glucosaminidase & + & + & + & - & + & - & + \\
\hline DNA G $+C$ content $(\mathrm{mol} \%)$ & 36.8 & 36.6 & 38.8 & 32.1 & ND & 36.8 & 37.8 \\
\hline
\end{tabular}


together with differential phenotypic properties, is sufficient to allocate strain $\mathrm{K}_{105^{\mathrm{T}}}$ to a species that is distinct from the recognized Chryseobacterium species (Stackebrandt \& Goebel, 1994). Therefore, on the basis of the data presented, strain $\mathrm{K}_{105^{\mathrm{T}}}$ should be classified in the genus Chryseobacterium as a member of a novel species, for which the name Chryseobacterium daeguense sp. nov. is proposed.

\section{Description of Chryseobacterium daeguense sp. nov.}

Chryseobacterium daeguense (dae.gu.en'se. N.L. neut. adj. daeguense of Daegu, Korea, from where the type strain was isolated).

Cells are Gram-negative, aerobic rods $(0.4-0.6 \times 0.8-$ $5.0 \mu \mathrm{m})$; a few cells are oval or coccoid. No flagellum is detected. Non-motile. Good growth on TSA, nutrient agar and R2A agar; no growth on MacConkey agar. Colonies on TSA are circular, convex, smooth, glistening, light yellow and $2.0-3.0 \mathrm{~mm}$ in diameter after 2 days of incubation at $30{ }^{\circ} \mathrm{C}$. The optimal temperature for growth is $30-37^{\circ} \mathrm{C}$. Growth occurs at 10 and $41^{\circ} \mathrm{C}$, but not at 5 or $42^{\circ} \mathrm{C}$. The optimal $\mathrm{pH}$ for growth is 6.5-7.5; growth occurs at $\mathrm{pH} 5.5$ and 9.0 , but not at $\mathrm{pH} 5.0$ or 9.5. Growth occurs in the presence of $0-2.0 \%(\mathrm{w} / \mathrm{v}) \mathrm{NaCl}$; optimal growth occurs in the presence of $0-1.0 \%(\mathrm{w} / \mathrm{v}) \mathrm{NaCl}$. No anaerobic growth is observed on plain TSA or on TSA supplemented with potassium nitrate. Oxidase- and catalase-positive. Tyrosine and Tweens 20, 40, 60 and 80 are hydrolysed, but hypoxanthine and xanthine are not. Arginine dihydrolase, lysine decarboxylase, ornithine decarboxylase and tryptophan deaminase are absent. Flexirubin-type pigments are produced. Susceptible to carbenicillin, chloramphenicol, lincomycin, novobiocin, oleandomycin, streptomycin and tetracycline, but not to ampicillin, cephalothin, gentamicin, kanamycin, neomycin, penicillin $G$ or polymyxin $B$. The predominant menaquinone is MK-6. The major fatty acids ( $>10 \%$ of total fatty acids) are iso- $\mathrm{C}_{15: 0}$, iso- $\mathrm{C}_{17: 1} \omega 9 \mathrm{c}$, iso- $\mathrm{C}_{17: 0} \quad 3-\mathrm{OH}$ and summed feature 3 (comprising $\mathrm{C}_{16: 1} \omega 7 c$ and/or iso- $\left.\mathrm{C}_{15: 0} 2-\mathrm{OH}\right)$. The DNA G $+\mathrm{C}$ content is $36.8 \mathrm{~mol} \%$ (determined by HPLC). Other phenotypic characteristics are given in Table 1 and Supplementary Table S1.

The type strain, $\mathrm{K}_{105^{\mathrm{T}}}\left(=\mathrm{KCTC} 12841^{\mathrm{T}}=\mathrm{JCM} 14362^{\mathrm{T}}\right)$, was isolated from wastewater collected from a textile dye works in Daegu, Korea.

\section{Acknowledgements}

This work was supported by the 21C Frontier program of Microbial Genomics and Applications (grant MG05-0401-2-0) from the Ministry of Science and Technology (MOST) of the Republic of Korea.

\section{References}

Bowman, J. P. (2000). Description of Cellulophaga algicola sp. nov., isolated from the surfaces of Antarctic algae, and reclassification of
Cytophaga uliginosa (ZoBell and Upham 1944) Reichenbach 1989 as Cellulophaga uliginosa comb. nov. Int J Syst Evol Microbiol 50, 1861-1868.

Cowan, S. T. \& Steel, K. J. (1965). Manual for the Identification of Medical Bacteria. London: Cambridge University Press.

de Beer, H., Hugo, C. J., Jooste, P. J., Vancanneyt, M., Coenye, T. \& Vandamme, P. (2006). Chryseobacterium piscium sp. nov., isolated from fish of the South Atlantic Ocean of South Africa. Int J Syst Evol Microbiol 56, 1317-1322.

Gallego, V., Garcia, M. T. \& Ventosa, A. (2006). Chryseobacterium hispanicum sp. nov., isolated from the drinking water distribution system of Sevilla, Spain. Int J Syst Evol Microbiol 56, 1589-1592.

Kämpfer, P., Dreyer, U., Neef, A., Dott, W. \& Busse, H.-J. (2003). Chryseobacterium defluvii sp. nov., isolated from wastewater. Int J Syst Evol Microbiol 53, 93-97.

Kim, K. K., Bae, H.-S., Schumann, P. \& Lee, S.-T. (2005). Chryseobacterium daecheongense sp. nov., isolated from freshwater lake sediment. Int J Syst Evol Microbiol 55, 133-138.

Komagata, K. \& Suzuki, K. (1987). Lipids and cell-wall analysis in bacterial systematics. Methods Microbiol 19, 161-203.

Lanyi, B. (1987). Classical and rapid identification methods for medically important bacteria. Methods Microbiol 19, 1-67.

Park, M. S., Jung, S. R., Lee, K. H., Lee, M.-S., Do, J. O., Kim, S. B. \& Bae, K. S. (2006). Chryseobacterium soldanellicola sp. nov. and Chryseobacterium taeanense sp. nov., isolated from roots of sanddune plants. Int J Syst Evol Microbiol 56, 433-438.

Quan, Z.-X., Kim, K. K., Kim, M.-K., Jin, L. \& Lee, S.-T. (2007). Chryseobacterium caeni sp. nov., isolated from bioreactor sludge. Int J Syst Evol Microbiol 57, 141-145.

Reichenbach, H. (1992). The order Cytophagales. In The Prokaryotes. A Handbook on the Biology of Bacteria: Ecophysiology, Isolation, Identification, Applications, 2nd edn, pp. 3631-3675. Edited by A. Balows, H. G. Trüper, M. Dworkin, W. Harder \& K. H. Schleifer. New York: Springer.

Sasser, M. (1990). Identification of bacteria by gas chromatography of cellular fatty acids. MIDI Technical Note 101. Newark, DE: MIDI Inc.

Shen, F.-T., Kämpfer, P., Young, C.-C., Lai, W.-A. \& Arun, A. B. (2005). Chryseobacterium taichungense sp. nov., isolated from contaminated soil. Int J Syst Evol Microbiol 55, 1301-1304.

Stackebrandt, E. \& Goebel, B. M. (1994). Taxonomic note: a place for DNA-DNA reassociation and 16S rRNA sequence analysis in the present species definition in bacteriology. Int J Syst Bacteriol 44, 846-849.

Tai, C.-J., Kuo, H.-P., Lee, F.-L., Chen, H.-K., Yokota, A. \& Lo, C.-C. (2006). Chryseobacterium taiwanense sp. nov., isolated from soil in Taiwan. Int J Syst Evol Microbiol 56, 1771-1776.

Tamaoka, J. \& Komagata, K. (1984). Determination of DNA base composition by reverse-phase high-performance liquid chromatography. FEMS Microbiol Lett 25, 125-128.

Vandamme, P., Bernardet, J.-F., Segers, P., Kersters, K. \& Holmes, B. (1994). New perspectives in the classification of the flavobacteria: description of Chryseobacterium gen. nov., Bergeyella gen. nov., and Empedobacter nom. rev. Int J Syst Bacteriol 44, 827-831.

Weon, H.-Y., Kim, B.-Y., Yoo, S.-H., Kwon, S.-W., Cho, Y.-H., Go, S.-J. \& Stackebrandt, E. (2006). Chryseobacterium wanjuense sp. nov., isolated from greenhouse soil in Korea. Int J Syst Evol Microbiol 56, 1501-1504.

Yoon, J.-H., Kim, H., Kim, S.-B., Kim, H.-J., Kim, W. Y., Lee, S. T., Goodfellow, M. \& Park, Y.-H. (1996). Identification of Saccharomonospora strains by the use of genomic DNA fragments and rRNA gene probes. Int J Syst Bacteriol 46, 502-505. 
Yoon, J.-H., Lee, S. T. \& Park, Y.-H. (1998). Inter- and intraspecific phylogenetic analysis of the genus Nocardioides and related taxa based on 16S rRNA gene sequences. Int J Syst Bacteriol 48, 187-194.
Yoon, J.-H., Kang, K. H. \& Park, Y.-H. (2003). Psychrobacter jeotgali sp. nov., isolated from jeotgal, a traditional Korean fermented seafood. Int J Syst Evol Microbiol 53, 449-454. 